\title{
The Important Role of the Environment in Indonesian Language Learning
}

\author{
Muthia Bazaratul Jannah (19016034) \\ muthiabazaratul@gmail.com
}

The environment will never be separated from human life, even inlearning especially Indonesian language, the environment can be a very important thing important. One of them is the environment that can affect the quality of teaching and learning for teachers and students learners. As we know, environmental-based Indonesian language learning which can reduce the boredom experienced by students during language learning Indonesia. Based on this, teachers or educators are required to be able to develop creativity in using the environment as a source and medium in learning.

Ramadhan et al, (2019: 2) say that environmental education can help students rethink the relationship or correlation between humans and their environment. The correlation starts from understanding the environment, knowing or being aware of the problem environment, and consider environmental issues related to life man. In addition, with this environment-based learning, students will be more sensitive and care about environmental conditions. Thus, teachers take advantage of the environment to train, familiarize, and motivate students to think critically and creatively. Sukma et al, (2016) argued that not only students, teachers also need to think creatively in use the environment to be used as a learning media. With various materials Indonesian language lessons that use text, the teacher can give examples of discourse or environmental themed text. Therefore, the teacher as an educator is also a facilitator for students. This is in line with the opinion of Sukma (2012: 434) and Ramadhan et al al, (2019: 1569) that teachers function as facilitators and managers of learning in learning process.

According to Sukma and Ahmad (2016: 3) creative teachers will be liked by students and teachers who are creative in the cognitive, affective, and psychomotor domains have roles and functions which can develop students' personality. Regarding the relationship between student creativity and environment, Munandar (in Piliang et al, 2014) says that creativity is a the result of the interaction of individuals with their environment, it is clear that individual creativity is largely determined by encouragement or motivation from within and the environment. Environment also able to influence the language and how students act talk with other students. The things that have been mentioned before will later relate and affect student learning outcomes. This statement is in line with the opinion of Zulhafizh et al, (2013) that students' attitudes and learning motivation contribute to learning outcomes, namely the Indonesian language. Sukma et al, (2017: 145) say that in foster student motivation to learn, teachers have an important role in taking a stand. This is reinforced by Slameto's opinion (in Tanjung et al, 2013) that learningis a process of behavior change as a result of interaction with environment to meet their needs. This learning process will continue to learning outcomes whose existence is still related to human interaction with students environment. 
We can exemplify the activities and relationships of students with the environment as follows. When students are given writing assignments. For example, writing poetry or short stories, the environment can be a source or media for supporting ideas for students, whether it's writing with environmental themes or write by looking at the phenomena that occur in the surrounding environment, because there are many an example of a text that can be produced by students by observing their environment, is not only in the form of literary texts but also in the form of non-literary texts. Indriyani et al, (2019) too said that providing an example in terms of literacy activities, namely knowledge environment of the text with the theme of the environment. Putri and Syahrul (2019: 66) stated that ideas in writing can be in the form of facts, experiences, observations, research, thinking or analyzing a problem. To get all of that, of course, can't be separated of the role of the environment. In other words, facts, experiences, observations, research, thinking and analysis of a problem obtained from the environment.

Based on the questionnaire that the author distributed about the "Important Role of the Environment in" Indonesian Language Learning" with 10 statements to 30 respondents consisting of Padang State University students semester 1 and 5, Bengkulu University students semester 5, student of Syiah Kuala University in semester 5, student of the Institute of Technology Padang 5th semester, Padang State Pelitechnic students 1st semester, University students Bung Hatta 5th semester, 5th semester Adzkia University student, High School student 5th semester of Health Sciences, and 5th semester students of the Academy of Finance and Banking. Of the total number of respondents, 26 respondents are more dominant and male 4 respondents with the percentage of women $86.7 \%$ and men $13.3 \%$.

Based on the results of the data from the percentage of questionnaires that have been carried out through the google form The results can be seen as follows: the first question, "The environment is an inspiration in " making a literary work" 40\% said strongly agree, $60 \%$ said agree, $0 \%$ said they did not agree, and $0 \%$ said they did not agree. The second statement, "Making examples of literary texts with environmental themes in student textbooks in learning Indonesian" 30\% said strongly agree, $70 \%$ said agree, $0 \%$ said disagree, and $0 \%$ say they don't agree. The third statement, "Knowing age appropriateness readers of literary works with environmental themes" $33.3 \%$ said strongly agree, 50\% said they agreed, $16.7 \%$ said they did not agree, and $0 \%$ said they did not agree. The fourth statement, "Creating a literary work with an environmental theme" $33.3 \%$ said strongly agree, $66.7 \%$ said agree, $0 \%$ said disagree, and $0 \%$ said do not agree. The fifth statement, "Creating a literary work with an environmental theme. Someone is able to make literary works (short stories) from observing the environment" $36.7 \%$ said strongly agree, $63.3 \%$ said agree, $0 \%$ said disagree, and $0 \%$ say disagree. The sixth statement, "The environment can be an inspiration for someone in making poetry" 40\% said strongly agree, $60 \%$ said agree, $0 \%$ said they did not agree, and $0 \%$ said they did not agree. The seventh statement, "When communicate with different environments such as one's race, ethnicity, culture, and language must use Indonesian" 45\% said strongly agree, 55\% said agree, 
$0 \%$ said they did not agree, and 0\% said they did not agree. The eighth statement, 'Novel Salah Asuhan' is based on a true story of life in Indonesian society in the past" $40 \%$ said strongly agree, $53.3 \%$ said agree, $6.7 \%$ said they did not agree, and $0 \%$ said they did not agree. The ninth statement, "Someone will be motivated to learn Indonesian due to the friendly environment use Indonesian" 53.3\% said strongly agree, 40\% said agree, $6.7 \%$ said they did not agree, and $0 \%$ said they did not agree. The tenth statement, "Story The fable The Monkey Who Likes to Lie describes human habits in everyday life. days" 36.7\% said strongly agree, 53.3\% said agree, 10\% said less agree, and $0 \%$ said they did not agree.

Based on the results of the questionnaire distribution that has been carried out as above, it can be concluded that: The author concludes that the environment has a very important relationship, role, benefit in learning Indonesian. It is proven by filling out a questionnaire by 30 respondents distributed by the author, the dominant respondents strongly agree and agree with the important role environment for learning Indonesian. Students can understand and are well aware of the important role of the environment in learning Indonesian. So, According to the author, public awareness, especially teachers, students, and students towards The important role of the environment in learning Indonesian can be categorized good. The application of the important role of the environment in learning Indonesian can make it easier for educators and students in the teaching and learning process and apply it in learning Indonesian that is more interesting, fun, motivating, and useful to students. 


\section{References}

Indriyani, V. Zaim, M., Atmazaki, A., dan Syahrul Ramadhan. (2019). Literasi Baca Tulis dan Inovasi Kurikulum Bahasa. KEMBARA Journal of Scientific Language Literature and Teaching, 5(1), 108-118.

Piliang, Wilda Srihastuty Handayani, Atmazaki, dan Syahrul Ramadhan. (2014). Kontribusi Kemampuan Apresiasi Sastra dan Berpikir Kreatif terhadap Keterampilan BermainDrama pada Siswa Kelas XII IPS SMA Negeri 2 Rengat Kabupaten Indragiri Hulu. Jurnal Bahasam Sastra dan Pembelajaran, 2(2).

Putri, Ranti Dwi dan Syahrul Ramadhan. (2019). Pengaruh Penggunaan Teknik Think TalkWrite (TTW) terhadap Keterampilan Menulis Teks Fabel Siswa Kelas VII SMP Negeri 31 Padang. Jurnal Pendidikan Bahasa dan Sastra Indonesia, 8(2).

Ramadhan, S., Sukma, E., dan Vivi Indriyani. (2019). Environmental Education and Disaster Mitigation Through Language Learning. IOP Conference Series: Earth and Environmental Scienc, 314(1), p. 1-9.

Ramadhan, Syahrul, Sukma, Elfia, dan Vivi Indriyani. (2019). Persepsi Guru terhadap Penggunaan Bahan Ajar Bahasa Indonesia dengan Perangkat Seluler dan Aplikasi Edmodo. Seminar Internasional Riksa Bahasa.

Sukma, Elfia. (2012). Pembelajaran Sastra yang Integratif Berbasis Kompetensi. International Conference on Languages and Arts, Halaman 432-436.

Sukma, Elfia dan Ahmad Johari Sihes. (2016). Kompetensi Kognitif Pembelajaran Apresiasi Sastra di Sekolah Dasar. Jurnal Penelitian Bahasa dan Sastra Indonesia, Volume 2.

Sukma, Elfia, Mahjuddin, Ritawati, dan Rizky Amelia. (2017). Literacy Media Development in Improving Reading and Writing Skill of Early Class Students in Elementary School Padang Utara Padang. Advances in Social Science, Education and Humanities Research, Volume 118.

Tanjung, Hasian Romadon, Ramadhan, S., dan Harris Effendi Thahar. (2013). Pengaruh Model Pembelajaran Kooperatif Tipe Think Pair Share dan Tipe Two Stay Two Stray terhadap Hasil Belajar Bahasa Indonesia Siswa Kelas X SMA Negeri 1Angkola Barat Kabupaten Tapanuli Selatan. Jurnal Bahasa, Sastra dan Pembelajaran, 1(1).

Zulhafizh, Atmazaki, dan Syahrul Ramadhan. (2013). Kontribusi Sikap dan Motivasi Belajar Siswa teqrhadap Hasil Belajar Bahasa Indonesia. Jurnal Bahasa, Sastra dan Pembelajaran, 2(2), 13-28. 